\title{
A VIAGEM REDONDA: HABEAS DATA, DIREITOS CONSTITUCIONAIS E AS PROVAS ILÍCITAS
}

\author{
LUÍS ROBERTO BARROSO ${ }^{1 *}$
}

I. Introdução. II - A efetividade das normas constitucionais. III Direitos subjetivos constitucionais $e$ as ações constitucionais. IV - $O$ habeas data. $V-U m$ novo desvio: a tolerância com as provas ilícitas

\section{INTRODUÇÃO}

Do ponto de vista histórico, vai-se tornando uma referência cada vez mais remota um dos grandes estigmas do regime militar ditatorial brasileiro, ao lado da violência física: a malversação de informações sobre a vida privada dos cidadãos. Inicialmente, tais dados, muitas vezes obtidos de forma ilegal, forneciam a matéria prima que alimentava a perseguição política, mesmo quando não havia qualquer imputação formal de violação da ordem jurídica. Mais à frente, na crescente patologia das ditaduras desgastadas, o uso indevido de informações comprava o silêncio e a adesão dos dissidentes do próprio regime, sob a ameaça de escândalos familiares e de publicidade de fatos da vida privada.

Esta terá sido, induvidosamente, a motivação mais imediata dos constituintes de 1988 para criação do habeas data, sendo certo que muitos deles próprios haviam sido vítimas desta modalidade de abuso de poder. Não se trata de instituto que tenha similar no direito comparado, nem que houvesse sido criado à vista de uma necessidade processual imperiosa. Tratou-se, acima de tudo, de uma reação ao passado, de valia primariamente simbólica.

O habeas data é um dos diversos remédios constitucionais previstos pela Constituição Federal. Até o regime anterior, as ações constitucionais clássicas do direito

1 Este texto foi escrito com a colaboração da advogada Ana Paula de Barcellos.

* Professor Titular de Direito Constitucional da Universidade do Estado do Rio de Janeiro; Master of Laws pela Universidade de Yale. Procurador do Estado e advogado no Rio de Janeiro.

R. Dir. Adm.,

Rio de Janeiro, 213: 149-163,

jul./set. 1998 
brasileiro eram o habeas corpus (1891). o mandado de segurança (1934) e a ação popular (1934). A Carta de 1988 ampliou significativamente este elenco, para nele incluir, além do habeas data, o mandado de injunção, o mandado de segurança coletivo e a ação civil pública, que fora recentemente introduzida no direito infraconstitucional.

Veja-se, a seguir, um esforço de enquadrar o habeas data dentro do contexto constitucional brasileiro presente, onde as questões mais vivas ainda são as de afirmação dos direitos subjetivos e de promoção da efetividade das normas constitucionais.

\section{CONSTITUIÇÃO E EFETIVIDADE}

\section{A frustração constitucional brasileira}

A experiência institucional brasileira é a história de uma recorrente frustração constitucional. Em menos de 200 anos de independência, tivemos oito Cartas Políticas, em um melancólico estigma de instabilidade e de falta de continuidade da ordem jurídica. Pior que isto: em seus períodos de vigência, a normatividade constitucional jamais foi capaz de efetivamente condicionar o processo político, limitando poderes $\mathrm{e}$ assegurando direitos.

Deste diagnóstico severo constata-se que os dois principais fatores de descrédito do constitucionalismo no Brasil têm sido a falta de efetividade de suas normas e a compulsão de renovar ou reformar a ordem constitucional. Do segundo mal não conseguimos nos libertar até os dias correntes: em menos de 10 anos de vigência, a Constituição de 1988 já caminha para sua vigésima emenda, sem contar as emendas de revisão. Sem embargo, no que diz respeito à busca pela efetividade, houve um avanço extremamente positivo e já é possível contabilizar algumas vitórias.

Com efeito, a ascensão doutrinária e jurisprudencial da Constituição à categoria incontestável de norma jurídica, conquanto pareça denotar uma obviedade, foi um salto de muitas décadas. Daí a importância do estudo das categorias de normas constitucionais, da tutela dos direitos e, especificamente, das ações que foram introduzidas para superar seu atávico descumprimento na experiência brasileira.

\section{A Constituição como norma jurídica. Tipologia das normas constitucionais}

Embora resulte de um impulso político, que deflagra o poder constituinte originário, a Constituição, uma vez posta em vigência, é um documento jurídico, é um sistema de normas. As normas constitucionais, como espécie do gênero normas jurídicas, conservam os atributos essenciais destas, dentre os quais a imperatividade. De regra, como qualquer outra norma, elas contêm um mandamento, uma prescrição, uma ordem, com força jurídica, e não apenas moral. Logo, a sua inobservância há de deflagrar um mecanismo próprio de coação, de cumprimento forçado, apto a 
garantir-lhe a imperatividade, inclusive pelo estabelecimento das consequiências da insubmissão ao seu comando. As disposições constitucionais são não apenas normas jurídicas, como têm um caráter hierarquicamente superior, não obstante a paradoxal equivocidade que longamente campeou nesta matéria, considerando-as prescrições desprovidas de sanção, mero ideário não-jurídico.

Disto resulta que o Direito Constitucional, tanto quanto os demais ramos da ciência jurídica, existe para realizar-se. Vale dizer: ele almeja à efetividade. Efetividade, já averbamos em outro estudo, designa a atuação da norma, fazendo prevalecer, no mundo dos fatos, os valores por ela tutelados. Ela simboliza a aproximação, tão íntima quanto possível, entre o dever-ser normativo e o ser da realidade social. Ao ângulo subjetivo, efetiva é a norma constitucional que enseja a concretização do direito que nela se substancia, propiciando o desfrute real do bem jurídico assegurado.

É à luz deste conceito básico de efetividade que se desenvolvem as idéias que se seguem.

Ao instituir o Estado, a Constituição (a) organiza o exercício do poder político, (b) define os direitos fundamentais do povo, e (c) estabelece princípios e traça fins públicos a serem alcançados. Por via de consequiência, as normas constitucionais podem ser agrupadas nas seguintes categorias:
A. Normas constitucionais de organização;
B. Normas constitucionais definidoras de direitos;
C. Normas constitucionais programáticas.

As normas constitucionais de organização traçam a estrutura do Estado, cuidando, essencialmente, da repartição do poder público e da definição da competência dos órgãos públicos. $\mathrm{Na}$ Carta em vigor, são exemplos de normas desta natureza as que instituem as competências do Executivo, Legislativo e Judiciário, bem como da União, Estados e Municípios. Embora não seja sua finalidade precípua, tais normas podem eventualmente gerar situações jurídicas individuais, sob a forma de direito subjetivo ${ }^{2}$.

As normas constitucionais definidoras de direito são as que tipicamente geram direitos subjetivos, investindo o jurisdicionado no poder de exigir do Estado - ou de outro eventual destinatário da norma — prestações positivas ou negativas, que proporcionem o desfrute dos bens jurídicos nelas consagrados. Nesta categoria se incluem todas as normas concernentes aos direitos individuais (e coletivos), políticos, sociais e difusos previstos na Constituiçāo.

As normas constitucionais programáticas veiculam princípios, desde logo observáveis, ou traçam fins sociais a serem alcançados pela atuação futura dos poderes públicos. Por sua natureza, não geram para os jurisdicionados a possibilidade de exigirem comportamentos comissivos, mas investem-nos na faculdade de demandar dos órgãos estatais que se abstenham de quaisquer atos que contravenham as diretrizes traçadas. Vale dizer: não geram direitos subjetivos na sua versão positiva, mas

2 Por exemplo, qualquer indivíduo pode opor-se judicialmente a uma restriçāo de direito imposta pelo Estado em matéria que a Constituiçāo haja deferido à competência dos Municípios ou da Uniāo. 
geram-no em sua feição negativa. São desta categoria as regras que preconizam a função social da propriedade (art. 170, III), a redução das desigualdades regionais e sociais (art. 170, VII), o apoio à cultura (art. 215), o fomento às práticas desportivas (art. 217), o incentivo à pesquisa (art.218) etc.

\section{DIREITOS SUBJETIVOS E AÇÕES CONSTITUCIONAIS}

Além de organizar o exercício do poder político, todas as Constituições modernas definem os direitos fundamentais dos indivíduos submetidos à soberania estatal. Embora existam dissenções doutrinárias, fulcradas, sobretudo, em sutilezas semânticas, e haja discrepância na linguagem do Direito Constitucional positivo, é possível agrupar os direitos fundamentais em quatro grandes categorias: direitos políticos, direitos individuais, direitos sociais e direitos coletivos ou difusos.

Os direitos de participação política, ou apenas direitos políticos, abrangem o direito de nacionalidade e o direito de cidadania. Pelo primeiro, o indivíduo é incorporado na comunhão nacional para uma série de efeitos, que compreendem prerrogativas e deveres. Pelo segundo, se reconhece ao indivíduo, qualificado por certos requisitos, a capacidade eleitoral (intervenção pelo voto na composição dos órgãos do Estado) e a capacidade eletiva (participação pessoal na composição dos órgãos do Estado) ${ }^{3}$. $\mathrm{Na}$ Carta de 5 de outubro de 1988, os direitos políticos dão nome ao capítulo IV do título II, compreendendo os artigos 14 a 16 . O art. 12 cuida da nacionalidade e o art. 17 rege os partidos políticos.

Os direitos individuais, de origem marcada pelo jusnaturalismo, tiveram como primeira manifestação “legislativa” a Declaração de Direitos inglesa, de $1689^{4}$. Não obstante, o seu ciclo de formação e aperfeiçoamento encontra-se mais ligado ao pensamento iluminista francês do século XVIII e à Declaração dos Direitos do Homem e do Cidadão, de 1789. Os direitos individuais, frequientemente denominados de liberdades públicas ${ }^{5}$, são a afirmação jurídica da personalidade humana. Talhados no individualismo liberal e dirigidos à proteção de valores relativos à vida, à liberdade, à segurança e à propriedade, contêm limitações ao poder político, traçando a esfera de proteção juridica do individuo em face do Estado. Os direitos individuais, impõem, em essência, deveres de abstenção aos órgãos públicos, pre-

M. Seabra Fagundes, ob. cit., p. 171-173.

4 Afonso Arinos de Melo Franco, Curso de Direito Constitucional Brasileiro, 1968 p. 155-156, Fernando Whitaker da Cunha identifica no advento do Cristianismo o ponto de partida dos direitos humanos (Democracia e Cultura, 1973, p. 344). Não se deve esquecer a Magna Charla, de 1215, primeiro documento escrito de limitaçāo ao poder monárquico absoluto, atentando-se, no entanto, que, escrita em latim, só veio a ser traduzida no século XVI para o inglês: "conquista das classes privilegiadas, eram os homens cultos que a invocavam e que dela extraíam o seu conteúdo político" (Marcelo Caetano, Direito Constitucional. 1987, p. 68).

5 Assim é na doutrina francesa (v. Georges Burdeau, Les Libertés Publiques, 1972, p. 13 e segs.). Vejam-se, também, José Cretella Júnior, Curso de Liberdades Públicas, 1986, e Celso Ribeiro Bastos, Curso de Teoria do Estado e Ciência Política, 1986, p. 138. 
servando a iniciativa e a autonomia dos particulares. Na Carta de 1969, vinham deduzidos, precipuamente, no art. 153. No texto atual, concentram-se em extensa - por vezes prolixa - enunciação nos 77 incisos do art. 5o.

Os direitos econômicos, sociais e culturais, identificados, abreviadamente, como direitos sociais, são de formação mais recente, remontando à Constituição mexicana, de 1917 , e à de Weimar, de 1919. Sua consagração marca a superação de uma perspectiva estritamente liberal, em que se passa a considerar o homem para além de sua condição individual. Com eles surgem para o Estado certos deveres de prestações positivas, visando à melhoria das condições de vida e à promoção da igualdade material. A intervenção estatal destina-se a neutralizar as distorções econômicas geradas na sociedade, assegurando direitos afetos à segurança social, ao trabalho, ao salário digno, à liberdade sindical, à participação no lucro das empresas, à educação, ao acesso à cultura, dentre outros. Enquanto os direitos individuais funcionam como um escudo protetor em face do Estado, os direitos sociais operam como "barreiras defensivas do indivíduo perante a dominação econômica de outros indivíduos" 6 .

As últimas duas décadas assistiram ao desenvolvimento florescente de uma nova categoria de direitos, ditos coletivos ou difusos, que apresentam peculiaridades próprias. Não versam eles interesses que tenham titular certo, apto a desfrutar, individualmente, determinado bem jurídico. Ao contrário, tais direitos caracterizamse por pertencerem a uma pluralidade indeterminada de sujeitos e pela indivisibilidade de seu objeto, de forma tal que a satisfação de um dos seus titulares implica na satisfação de todos, do mesmo passo que a lesão de um só constitui, ipso facto, lesão da inteira coletividade. Integram essa natureza de direitos a preservação do meio-ambiente, a defesa da qualidade dos produtos e a garantia contra a manipulação dos mercados (proteçāo ao consumidor) e a salvaguarda de valores culturais e espirituais (proteção ao patrimônio histórico, artístico e estético). Estes direitos foram positivados em Constituições mais modernas, como a portuguesa (1976) e espanhola (1978) e encontram-se previstos em múltiplos dispositivos da Constituição brasileira (e.g. arts. $5^{\circ}$, XXXII, LXXIII e 225). Na legislação ordinária foram desenvolvidos em documentos legislativos de grande significação, como a Lei de Ação Civil Pública (Lei 7.347, de 24.07.85) e o Código do Consumidor (Lei 8.078, de 11.09.90).

A idéia central em torno da qual gravita o tópico ora desenvolvido é a de direito subjetivo, entendido como o poder de ação, assente no direito objetivo, e destinado à satisfação de certo interesse ${ }^{7}$. A norma jurídica de conduta caracteriza-se por sua

6 Celso Antonio Bandeira de Mello, ob. cit., p. 8.

7 M. Seabra Fagundes, ob. cit., p. 169. Embora não haja referência do autor, esta definição identifica-se, em seus elementos essenciais, com as de Ruggiero e Maroi, Michoud e Trotabas e Ferrara (v. Caio Mário da Silva Pereira, Instituições de Direito Civil, vol I, 1974, p. 42). Ela tem conteúdo eclético, no sentido de que utiliza, conjugadamente, elementos da teoria da vontade, de Windscheid, pela qual o direito subjetivo é o poder de ação assegurado pela ordem jurídica, e a teoria do interesse, de Ihering, para quem ele é um interesse juridicamente protegido (v. José Carlos Moreira Alves, Direito Romano, vol. 1, 1987, p. 104 e Caio Mário da Silva Pereira, ob. cit.. p. 40-3). 
bilateralidade. dirigindo-se a duas partes e atribuindo a uma delas a faculdade ${ }^{8}$ de exigir da outra determinado comportamento. Forma-se, desse modo, um vínculo, uma relação jurídica que estabelece um elo entre os dois componentes: de um lado, o direito subjetivo, a possibilidade de exigir; de outro, o dever jurídico, as obrigações a cumprir ${ }^{9}$. Quando a exigibilidade de uma conduta se verifica em favor do particular em face do Estado, diz-se existir um direito subjetivo público.

Singularizam o direito subjetivo, distinguindo-o de outras posições jurídicas, a presença. cumulada, das seguintes características ${ }^{10}$ : a) a ele corresponde sempre um dever jurídico; b) ele é violável, ou seja, existe a possibilidade de que a parte contrária deixe de cumprir o seu dever; c) a ordem jurídica coloca à disposição de seu titular um meio jurídico - que é a ação judicial - para exigir-lhe o cumprimento, deflagrando os mecanismos coercitivos e sancionatórios do Estado.

Reconhecendo, embora, que a noção de direito subjetivo, tomada por empréstimo ao direito privado, encontra-se à espera de sua versão publicizada, as normas constitucionais definidoras de direitos são aquelas que correspondem ao esquema acima figurado $^{1 \dagger}$. Delas resultam para os seus beneficiários - os titulares do direito — situações jurídicas imediatamente desfrutáveis, efetivadas por prestações positivas

8 É pertinente, aqui, o emprego da palvra faculdade, como fazem inúmeros autores, porque, em verdade, o titular do direito pode fazer ou não uso da norma para exigir a efetivação da conduta prevista. Faculdade designa, precisamente, a possibilidade de praticar ou não determinado ato, sem um correspectivo dever jurídico a outrem (v. Arnold Wald, Curso de Direito Civil, vol. I, 1962, p. 136).

9 V. José Carlos Moreira Alves, ob. cit. p. 103. Utilizou-se a idéia de direito subjetivo por seu caráter universal e aceitaçāo relativamente pacífica, apesar de objeçōes respeitáveis, como as de Hans Kelsen e Leon Duguit, cujos fundamentos não cabe aqui comentar e aos quais não aderimos. Aceitamos, todavia, que os direitos subjetivos sejam a espécie principal do gênero situaçāo jurídica subjetiva (ativa ou de vantagem). que compreende, também, pelo menos - para nāo avançar em tema polêmico - os interesses legítimos e as faculdades. Para aprofundamento dessa questão, com ampla referência doutrinária. veja-se José Afonso da Silva, ob. cit.. p. 153 e segs.

10 San Tiago Dantas. Programa de Direito Civil (Aulas proferidas na Faculdade Nacional de Direito, 1942-45), s. d.. p. 150.

II Não se está aqui de acordo com a existência de uma categoria diversa, identificável como direito, defendida por Celso Antonio Bandeira de Mello (ob. cit., p. 16-7). Segundo ele, preceitos que asseguram o "direito de ir e vir", o "direito de inviolabilidade do domicílio", o "direito de propriedade", não são concessivos de direitos, mas, sim, de poderes jurídicos. Não parece ser assim. A circunstância de uma situação concretizar-se por via de uma abstenção, de uma prestação negativa, nāo a desqualifica como direito. Existe uma relação jurídica entre o seu titular e o Estado ou o restante da coletividade, pela qual a um cabe exigir a abstençāo e aos outros o dever de absterem-se. Poder-se-ia,é verdade, qualificar, por exemplo, o "direito de ir e vir" como uma faculdade e, como tal, inviolável, por nāo coresponder a um dever de outrem. Mesmo assim, se alguém for ilicitamente tolhido na sua locomoção, haverá lesão, não à faculdade de ir e vir, mas à liberdade, esta. sim, um direito subjetivo. Portanto, no fundo, o resultado é o mesmo: a exigibilidade da abstenção (v. San Tiago Dantas, ob. cit. p. 149). À expressão poderes jurílicos convém reservar significado diverso. Neles, tal como nos direitos, existe um direito do sujeito ativo ao qual corresponde um dever do sujeito passivo. A peculiaridade, todavia, é que no caso do poder jurídico ele é exercido não em favor do sujeito ativo, mas do próprio sujeito passivo ou do grupo social. Exemplo típico, de direito privado, é o do pátrio poder (v. Arnold Wald. ob. cit., p. 137). No direito público, é o próprio poder estatal: "Les gouvernaments n'ont point le droit subjectif de commander. Ils ont seulement le pouvoir objectif de vouloir conformément au droit et d'asssurer par la contrainte la reálisation du droit" (v. Leon Duguit, "Études de Droit Public". 1901, vol. 2, p. 1). 
ou negativas, exigíveis do Estado ou de outro eventual destinatário da norma, inclusive por via de ação judicial, quando não entregues espontaneamente.

Por longo tempo sustentou-se que as declarações de direitos incorporadas às Constituições não seriam mais que princípios filosóficos e morais, sem valor jurídico $^{12}$. Diversos autores, principalmente europeus, atribuem à Constituição belga de 1832 - marcante documento na construção jurídica do Estado liberal a primazia na positivação desses direitos, por havê-los absorvido em seu texto, em lugar de conservá-los, como até então se fizera, em uma declaração apensa. Tal prelação, é bem de ver, teria de ser disputada com a Carta Imperial brasileira, de 1824, que, oito anos antes, já dera concreção jurídica a diverso direitos fundamentais, fazendo-os acompanhar, inclusive, das respectivas garantias (título $\mathbf{8}^{\mathbf{0}}$, especialmente o art. 179 - v. supra, cap. II, ítem 2) ${ }^{13}$. Mas, a rigor, a juridicização daqueles princípios éticos tocou, pioneiramente, ao "Bill of Rights" da Constituição norte-americana, consubstanciado nas suas dez primeiras emendas, ratificadas em 1791. E, quanto à sua gaı antia, não se deve ignorar o marco representado pela doutrina do controle da constitucionalidade das leis, elaborada pela Suprema Corte daquele país, em 1803.

A referência histórica é meramente ilustrativa. Modernamente, já não cabe negar o caráter jurídico e, pois, a exigibilidade e acionabilidade dos direitos fundamentais, na sua variedade tipológica. É puramente ideológica, e não científica, a resistência que ainda hoje se opõe à efetivação, por via coercitiva, dos chamados direitos sociais. Também os direitos políticos e individuais enfrentaram, como se assinalou, a reação conservadora até sua final consolidação. A afirmação dos direitos fundamentais como um todo, na sua exequiibilidade plena, vem sendo positivada nas Cartas Políticas mais recentes, como se vê do art. $2^{\circ}$ da Constituição portuguesa e do Preâmbulo da Constituição brasileira, que proclama ser o país um Estado democrático, "destinado a assegurar o exercício dos direitos sociais e individuais".

Ora bem: caracterizados os direitos constitucionais como direitos subjetivos, disto resulta que de sua violação nasce para o titular uma pretensão, exercitável mediante ações judiciais. $\mathrm{O}$ direito de ação tem lastro constitucional no art. 5을 XXXV ("a lei não excluirá da apreciação do Poder Judiciário lesão ou ameaça a direito”). Mas a maior parte das ações é instituída pela legislação infraconstitucional. Existe, todavia, uma específica gama de ações que têm cunho constitucional.

Tradicionalmente, no direito brasileiro, estas ações constitucionais eram o habeas corpus (1891), o mandado de segurança (1934) e a ação popular (1934). A Constituição de 1988, no entanto, inovou na matéria, ampliando, de modo signifi-

12 V. André Hauriou, Derecho Constitucional e Instituciones Políticas, 1971 (ed. espanhola), p. 220-221; Georges Burdeau, Droit Constitutionnel et Institurions Politiques, 1974, p. 73; Paulo Bonavides, Direito Constitucional, 1980, p. 184-190; A. Esmein, Élements de Droit Constitutionnel, 1921, p. 592; Carré de Malberg, Contribution à la Théorie Generale de l'Etat, II, 1922, p. 581 e Maurice Hauriou, Principes de Droit Public, 1910, p. 557-558.

13 Ada Pellegrini Grinover, Direitos e Garantias Individuais, in Constituição e Constituinte, 1987, p. 123. 
cativo. o elenco de ações constitucionais, aos quais adicionou: o mandado de segurança coletivo, o mandado de injunção e o habeas data, além de haver constitucionalizado a ação civil pública (art. 129, III).

\section{HABEAS DATA}

Uma das distorções mais agudas do ciclo militar-autoritário no Brasil, como já assinalado, foi o uso e, sobretudo, o abuso na utilização de informações que diferentes organismos armazenavam sobre pessoas. Logo cedo, a idéia de um serviço de inteligência voltado, elevadamente, para a segurança do Estado esvaiuse em tropicalismos diversos. Envolvendo-se na política ordinária, os órgãos da segurança mergulharam em terreno pantanoso de perseguições a adversários, operando freqüentemente nas fronteiras da marginalidade. A chamada comunidade de informações passou a constituir um poder paralelo e agressivo, que, por vezes sobrepunha-se, ao poder político institucional, valendo-se de meios ilícitos para fins condenáveis.

A rejeição formal dessa prática que se entranhara na cultura do poder no Brasil correspondia a um anseio político expressivo. Atendeu-o o constituinte por via do habeas data, um remédio cuja valia é, no fundo, essencialmente simbólica. O novo remédio foi abrigado no inciso LXXII do art. $5^{0}$ do texto constitucional:

\section{"LXXII - conceder-se-á habeas data:}

a) para assegurar o conhecimento de informações relativas à pessoa do impetrante, constantes de registros ou banco de dados de entidades governamentais ou de caráter público;

b) para a retificação de dados, quando não se prefira fazê-lo por processo sigiloso, judicial ou administrativo."

Anteriormente à promulgação da Lei 9.507, de 12.11.97, que passou a regular, em nível infraconstitucional, o direito de acesso a informações, e disciplinou o rito processual do habeas data, a doutrina e a jurisprudência já haviam traçado um perfil do novo instituto com base na lacônica dicção constitucional. É de valia percorrer as formulações que se desenvolveram antes do advento da lei específica, e que, em ampla medida, foram por ela incorporadas.

$\mathrm{Na}$ previsão constitucional, duplo é o objeto do habeas data: assegurar o conhecimento de informações e ensejar sua retificação. Estabeleceu-se, assim, que em um único habeas data o requerente teria, inicialmente, acesso às informações. Esta fase teria rito sumário, que poderia ser o do mandado de segurança ${ }^{14}$, até que o legislador ordinário viesse a optar pela edição de lei específica. Prestadas as

14 Sobre a adoçāo do procedimento do mandado de segurança, ao menos nesta $1^{\mathbf{a}}$ fase, vejam-se: em sede doutrinária, Calmon de Passos, Mandado de Segurança Coletivo, Mandado de Injunção, Habeas Data, Constituição e Processo. Rio de Janeiro, Ed. Forense, 1989, p. 148; em sede jurisprudencial, $H D$ 1-DF. julgado pelo TFR, rel. Min. Milton Pereira, DJ de 02.05.89. 
informações, se o impetrante se satisfizesse, seria extinto o processo. Caso ele desejasse retificá-las, seria instaurada uma segunda fase, não mais de caráter mandamental, mas cognitivo, onde então realizar-se-ia a instrução do feito, em regime contraditório. Note-se que a jurisprudência havia rejeitado a idéia de habeas data preventivo ${ }^{15}$.

A jurisprudência anterior à lei específica havia se consolidado, igualmente, no sentido de somente ser cabível o habeas data se em via administrativa tiver ocorrido a negativa no fornecimento das informações. Faltará interesse em agir se o interessado não houver previamente formulado requerimento ao detentor da informação pretendida ${ }^{16}$. A matéria foi objeto da Súmula $n^{0} 2$, do Superior Tribunal de Justiça: "Não cabe o habeas data (CF, art. 5, LXXII, a) se não houve recusa de informações por parte da autoridade administrativa". Assinale-se que, ao contrário do que ocorre com o habeas corpus ${ }^{17}$, exige-se, para a impetração de habeas data, a prévia constituição de advogado habilitado, que deverá juntar instrumento de mandato ${ }^{18}$.

No que diz respeito à legitimação ativa, o entendimento que se firmou é de que o direito de conhecer e retificar dados, bem como o de impetrar habeas data, é personalíssimo $^{19}$, embora exista pelo menos um precedente perante Tribunal superior em que se reconheceu legitimidade a herdeiro e a cônjuge supérstite ${ }^{20}$. Legitimados passivos são os órgãos da Administração direta e indireta, bem como as pessoas privadas que prestem serviços públicos ou de utilidade pública, ou prestem serviços ao público, como, e. g., os de proteção ao crédito. Não cabe ao âmbito do habeas data a apuração e responsabilização do autor da informação objeto da impetração ${ }^{21}$.

$\mathrm{O}$ direito material de acesso às informaçōes, tutelável por via do habeas data, não é, todavia, absoluto. A própria Constituição limita-o, no inciso XXXIII do art. $5^{\underline{o}}$, ao ressalvar aquelas informações "cujo sigilo seja imprescindível à segurança da sociedade e do Estado”. Esta valoração, no entanto, não é da competência discricionária do órgão público que detém a informação, cabendo, ao revés, ao pronunciamento motivado da autoridade judiciária ${ }^{22}$.

A Lei 9.507, de 12.11.97, ao disciplinar as hipóteses de cabimento, reproduziu as duas tipificações do texto constitucional, acrescentando, no inciso III do seu art. $7^{0}$. uma terceira previsão. Confira-se a íntegra do dispositivo:

15 TFR, $H D$ 9-DF, rel. Min. Armando Rolemberg, DJ de 27.06.89.

16 STJ, $H D$ 5-DF, DJ de 28.08 .89 e $H D$ 8-DF, JSTJ $1 / 158$.

17 V. Lei 8.906 , de 04.07 .94 (EOAB), art. $1^{\mathrm{Q}}, \S 1^{\mathrm{Q}}$.

18 STF, $H D$ 15-5-SP, rel. Min. Octávio Gallotti, DJ de 17.02.89, p. 989.

19 José Afonso da Silva, Curso de Direito Constitucional Positivo, $13^{\mathrm{a}}$ ed., São Paulo, Malheiros Editores, p. 432; v. tb. TJ-MG, $H D$ 3-BH, Ac. unan. das Cam. Civ. Reuns., DO de 17.06.89.

20 TFR, $H D$ 1-DF (v. supra, nota 1).

21 TJ-RS, $H D$ 588058982, j. em 21.11.88.

22 É o que decidiu o TFR no $H D$ 1-DF (v. nota 1 supra): "Compete ao Judiciário examinar a alegação do sigilo. avaliando da sua procedência ou não, compatibilizando a segurança do Estado com o direito à revelação das informações pretendidas." 
"Art. 7" Conceder-se-á habeas data:

I - para assegurar o conhecimento de informações relativas à pessoa do impetrante, constantes de registros ou banco de dados de entidades governamentais ou de caráter público;

II - para a retificação de dados, quando não se prefira fazê-lo por processo sigiloso, judicial ou administrativo;

III - para anotação nos assentamentos do interessado, de contestação ou explicação sobre dado verdadeiro mas justificável e que esteja sob pendência judicial ou amigável."

O habeas data, como visto, pode ser requerido para obtenção de informações constantes tanto de registros ou bancos de dados públicos como privados, desde que tenham caráter público. O parágrafo único do art. $1^{\circ}$ considera de caráter público "todo registro ou banco de dados contendo informações que sejam ou que possam ser transmitidas a terceiros ou que não sejam de uso privativo do órgão ou entidade produtora ou depositária das informações".

A Lei 9.507/97, aliás na mesma linha da jurisprudência que se firmara antes de sua edição. estabeleceu determinados pressupostos, que funcionam como condições específicas para o ajuizamento da ação de habeas data, consoante previsão do parágrafo único de seu art. $8^{\circ}$, in verbis:

“Art. 8".

Parágrafo único. A petição inicial deverá ser instruída com prova:

$I$ - da recusa ao acesso às informaçōes ou do decurso de mais de dez dias sem decisão;

II - da recusa em fazer-se a retificação ou do decurso de mais de quinze dias, sem decisão; ou

III - da recusa em fazer-se a anotação a que se refere o $\S 2^{\underline{Q}}$ do art. $4^{\underline{o}}$ ou do decurso de mais de quinze dias sem decisão."

$O$ art. 13 especifica o conteúdo da prestação jurisdicional a ser entregue, remarcando o caráter mandamental do pronunciamento, ao prever:

“Art. 13. Na decisão, se julgar procedente o pedido, o juiz marcará data e horário para que o coator:

I - apresente ao impetrante as informações a seu respeito, constantes de registros ou banco de dados; ou

II - apresente em juízo a prova da retificação ou da anotação feita nos assentamentos do impetrante."

A Lei contém, ainda, regras específicas de competência (art. 20) e disposições de cunho procedimental, valendo destacar o estabelecimento de prioridade nos processos de habeas data sobre todos os atos judiciais, exceto habeas corpus e mandado de segurança (art. 19), bem como a gratuidade do procedimento administrativo para o acesso às informações e retificação de dados, bem como para a ação de habeas data propriamente dita (art. 21).

O habeas data suscita menor número de questões controvertidas que outras ações constitucionais introduzidas ou constitucionalizadas em 1988, como o man- 
dado de injunção - em relação ao qual não se obteve pacificação sequer quanto ao objeto -, o mandado de segurança coletivo e a ação civil pública, que se debatem até hoje com intrincadas questões referentes à legitimação ativa.

\section{UM NOVO DESVIO: A TOLERÂNCIA COM A PROVA OBTIDA POR MEIO ILÍCITO}

O habeas data teve, como principal causa de sua criação, uma circunstância histórica já superada. Embora isto não venha a inibir sua aplicação a novas situações, é certo que os vilões já não são os mesmos.

Fora do espectro de incidência do habeas data, mas no mesmo domínio da ilicitude na obtenção e divulgação das informações, um novo e grave desvio esboça o caminho inverso da história. A despeito da letra clara da Constituição, materializada nos incisos XII e LIV do art. 5 - que, respectivamente, vedam a violação das comunicações individuais (salvo a exceção prevista pelo próprio inciso) e proíbe a utilização de prova obtida por meio ilícito no processo - a tolerância com esse fenômeno já vai se tornando uma patologia nacional.

Confira-se, antes de mais nada, o regime constitucional da matéria.

No Direito brasileiro, anteriormente à Constituição de 1988, a admissibilidade de provas ilícitas chegou a ser questão controvertida na doutrina e na jurisprudência. Havia, inclusive, abalizada opinião doutrinária defendendo que a aceitação ou não de provas obtidas por meios ilícitos haveria de verificar-se casuisticamente, tendo em vista a proporcionalidade entre o direito lesado pela obtenção da prova ilícita e os interesses beneficiados por sua admissão no processo. ${ }^{23}$ Sem embargo, a jurisprudência predominante foi no sentido de sua inadmissibilidade tout court.

De fato, o Supremo Tribunal Federal pronunciou-se, reiteradamente, neste sentido, como se vê, e.g., das decisões proferidas no RE $\mathrm{n}^{\mathrm{0}} 85.439-\mathrm{RJ}^{24} \mathrm{e}$ no $\mathrm{RE}$ $100.094 .^{25}$ Mais recentemente, em acórdão específico sobre a matéria, manifestou-se ainda uma vez a Corte, em decisão relatada pelo Ministro Célio Borja:

“1. Os meios de prova ilícitos não podem servir de sustentação ao inquérito policial ou à ação penal.

2. As provas produzidas no inquérito ora em exame - gravações clandestinas - além de afrontarem o princípio da inviolabilidade do sigilo das comunicações ( $\$ 9$ do art. 153, da CF) cerceiam a defesa e inibem o contraditório, em ofensa, igualmente, à garantia do $\$ 15$ do art. 153 da Lei Magna". ${ }^{26}$

23 José Carlos Barbosa Moreira, Temas de Direito Processual, $2^{\mathbf{a}}$ série, p. 9.

24 RTJ 84/609, Rel. Min. Xavier de Albuquerque: "Prova civil. Gravação magnética, feita clandestinamente pelo marido, de ligaçōes telefônicas da mulher. Inadmissibilidade de sua utilizaçāo em processo judicial, por não ser meio legal nem moralmente legítimo (art. 332 do CPC).

25 RTJ 110/978, Rafael Mayer: "Infringente da garantia constitucional do direito da personalidade e moralmente ilegítimo é o processo de captaçāo de prova, mediante a interceptaçāo de telefonema, à revelia do comunicante, sendo, portanto, inadmissível venha a ser divulgada em audiência de processo judicial, de que sequer é parte."

26 RHC nº 63.834-SP, Rel. Min. Célio Borja, in RTJ 122/47. 
Contudo, no contexto da Carta de 1988, qualquer discussão doutrinária acerca do tema perde relevância em face da peremptória vedação contida no texto constitucional. De fato, dispõe o art. 5ํ, LVI da Lei Fundamental em vigor:

"Art. 5".

LVI. são inadmissíveis, no processo, as provas obtidas por meios ilícitos".

$\mathrm{Na}$ verdade, a Constituição brasileira, por disposição expressa, retirou a matéria da discricionariedade do julgador e vedou a possibilidade de ponderação de bens e valores em jogo. Elegeu ela própria o valor mais elevado: a segurança das relações sociais pela proscrição da prova ilícita. Como constatou Ada Pellegrini Grinover, não há margem para aplicação do princípio da proporcionalidade, porque o constituinte não deu margem a qualquer exceção. ${ }^{27} \mathrm{O}$ sistema constitucional brasileiro partilha da "convicção de que a prova obtida por meios ilícitos deve ser banida do processo, por mais relevantes que sejam os fatos por ela apurados, uma vez que se subsume ela ao conceito de inconstitucionalidade, por vulnerar normas ou princípios constitucionais" 28

Reconhecendo, igualmente, a linguagem inequívoca do dispositivo constitucional, endossou Fernando da Costa Tourinho Filho:

"Hoje, contudo, a Constituição de 1988 proclama, no art. 5o, LVI, serem inadmissíveis, no processo, as provas obtidas por meios ilicitos. Se a Lei Maior assim o diz, evidente não mais poderem ser admitidas aquelas provas obtidas em afronta à dignidade humana e àqueles direitos fundamentais de que trata a Lei das Leis". ${ }^{29}$

Algumas decisões de Tribunais estaduais rejeitaram expressamente o aproveitamento da prova ilícita. ${ }^{30} \mathrm{O}$ Tribunal do Estado do Rio de Janeiro chegou a decidir:

"PROVA FONOGRÁFICA - ART. $5^{Q}$ - INC. LVI - CONSTITUIÇÃO FEDERAL DE 1988

São inadmissíveis, no processo, as provas obtidas por meios ilícitos (art. $5^{\circ}$, LVI da Constituição). Sendo invioláveis a intimidade e a vida privada, bem como o sigilo das comunicações, não se admite a prova obtida pela violação telefônica, em conversa de terceiros, ainda que se cuide de um dos cônjuges". 31

$\mathrm{Na}$ mesma linha doutrinária manifestou-se o Superior Tribunal de Justiça, in verbis:

27 Ada Pellegrini Grinover, A eficácia dos atos processuais à luz da Constituição Federal, in RPGESP $37 / 46$.

28 Ada Pellegrini Grinover. Interceptaçōes telefônicas e gravações clandestinas no processo penal, in Novas Tendências do Direito Processual (De acordo com a Constituição de 1988), p. 61-2.

29 Fernando da Costa Tourinho Filho, Processo Penal, Vol. III, 1993, p. 210.

30 RT 654/132: "A gravaçāo magnética de ligações telefônicas feita clandestinamente não é meio legal nem moralmente legítimo de produção de prova no processo". E RT 649/65: "Embora desnecessário, o legislador constituinte fez questão de enfatizar no artigo $5^{2}$. LVI, que "sāo inadmissíveis, no processo, as provas obtidas por meios ilícitos'. A questāo, portanto, deixou de se situar, como dispōe o CPC, no âmbito da autenticidade da reprodução, para alcançar a própria forma de obtenção da gravação e sua legitimidade e licitude".

31 AI nº 1.802/93. 4ㄹ CC, Rel. Des. Semy Glanz, in DO 06.10.94, p. 216. 
"O processo visa a projetar a verdade real. Admissivel, por isso, qualquer prova. A Constituição da República registra apenas uma ressalva: quando obtida por meios ilícitos (art. 5", LVI)". ${ }^{32}$

A posição do Supremo Tribunal Federal encontra-se exposta no voto condutor do Ministro Sepúlveda Pertence, no já referido HC 69.912-0-RS, onde deixou remarcado:

"No Brasil, contudo, a inadmissibilidade da prova captada ilicitamente já se firmara no Supremo Tribunal, antes da Constituição, seja no processo civil, seja na investigação criminal. E a Constituição de 1988 explicitou peremptoriamente, no art. 5o, LVI, que "säo inadmissiveis, no processo, as provas obtidas por meios ilícitos". No ponto, legem habemus: toda a discussão a respeito terá, no Brasil, sabor puramente acadêmico.

23. O que resta, pois, sem solução expressa na Constituição - e de relevo decisivo no caso - é a terceira questão, atinente às conseqüências processuais da admissāo no processo, não obstante a proibição consitucional ou legal, da prova ilicitamente obtida. (...)

26. Por isso, de minha parte, não iria além de conceder que a admissão da prova ilícita só não induz nulidade, quando irrelevante por seu objeto ou, então, quando se pudesse afirmar seguramente que outras provas, colhidas independentemente da existência daquela prova proibida, bastariam à condenaçẫo" ${ }^{33}$

A prova obtida por meio ilícito, portanto, vicia-se por manifesta nulidade, não podendo figurar validamente em qualquer processo judicial. No processo criminal, se for ela o único elemento de instrução constante da denúncia, impõe-se, como via de conseqüência, o trancamento da ação penal.

Nada obstante a limpidez dos preceptivos aplicáveis, o país tem incorporado à sua rotina sucessivas e impunes violações da disciplina constitucional da matéria. Nos jornais televisivos tem-se tornado constrangedora rotina a divulgação de gravações resultantes de interceptação telefônica clandestina. Recentemente, importante jornal do Rio de Janeiro divulgava que um determinado candidato a cargo eletivo majoritário já possuía diversas fitas gravadas incriminadoras do candidato adversário, que retrucou afirmando possuir outras tantas. Já há um mercado negro de provas ilícitas.

Sem embargo da patente incivilidade desse desvio, parte da jurisprudência e da doutrina têm demonstrado crescente predisposição para a flexibilização dos comandos constitucionais aplicáveis na matéria. De fato, escudados, sobretudo, na idéia de proporcionalidade e ponderação de valores, diversos autores têm endossado esta linha interpretativa, ${ }^{34}$ com repercussão nas decisões do Judiciário, inclusive do Superior Tribunal de Justiça ${ }^{35}$. A tese central é a de que se deve avaliar, em cada

32 REsp. 55.165-0-GO, Rel. Min.Luiz Vicente Cernicchiaro, in DJ 12.12.94, p. 34.384.

33 DJU 25.03.95, Rel. Min. Sepúlveda Pertence.

34 Confira-se: José Carlos Barbosa Moreira, A Constituição e as provas ilicitamente adquiridas, RDA 205/11; Nelson Nery Junior, Princípios do Processo Civil na Constituição Federal. 1992. p. 141 e ss. 35 STJ, HC 3982/95, DJ 26.02.96 e ROMS 6129/95, DJ 12.08 .95 
caso concreto, os interesses em jogo ( $v . g .:$ a preservação da intimidade versus o combate à criminalidade). Por este raciocínio, se a utilização de uma prova ilicitamente obtida em determinado processo conduzir a um resultado mais importante, do ponto de vista valorativo, justificar-se-ia o descumprimento do comando constitucional. ${ }^{36}$

Embora a idéia possa parecer tentadora e seja defendida por doutrinadores da maior suposição, deve-se ter em mente sempre a lição preciosa de Herbert Wechsler, em conferência proferida há várias décadas na Universidade de Harvard, em homenagem ao grande magistrado Oliver Wendell Holmes:

" $O$ que caracteriza as decisões judiciais, em contraste com os atos dos outros Poderes, é a necessidade de que sejam fundadas em princípios coerentes e constantes, e não em atos de mera vontade ou sentimento pessoal. Discordo, assim, com veemência, daqueles que, aberta ou encobertamente, sujeitam a interpretação da Constituição e das leis a um teste de virtude, para verificar se o resultado imediato limita ou promove seus próprios valores e crenças.

Quem julga com os olhos no resultado imediato, e em função das próprias simpatias ou preconceitos, regride ao governo dos homens, e não das leis. Nada é mais grave em Direito, nenhum problema é mais profundo do que este tipo de avaliação e de julgamento ad hoc". 37

$O$ entendimento flexibilizador dos dispositivos constitucionais citados, além de violar a diç̧ão claríssima da Carta Constitucional, é de todo inconveniente em se considerando a realidade político-institucional do País. Não se ignora que a atividade interpretativa, embora se almeje neutra, nunca é objetiva. A valoração das questões envolvidas é inerente à atividade jurídica e seria ingenuidade acreditar diferente. Entretanto, como já deixamos averbado em outra oportunidade, a interpretação gramatical do texto constitucional traça os limites dentro dos quais o intérprete exercerá o seu ofício ${ }^{38}$. Embora seja mesmo difícil que um vocábulo tenha significação inequívoca, há sentidos mínimos que devem ser respeitados, sob o risco de se perverter o seu papel de transmissor de idéias e significados.

Embora a idéia da proporcionalidade possa parecer atraente, deve-se ter em linha de conta os antecedentes de País, onde as exceções viram regra desde sua criação (vejam-se, por exemplo, as medidas provisórias). À vista da trajetória inconsistente do respeito aos direitos individuais e da ausência de um sentimento constitucional consolidado, não é nem conveniente nem oportuno, sequer de lege ferenda, enveredar por flexibilizações arriscadas.

Não se deve perder de vista que, nos dias obscuros e prepotentes do regime militar, boa parte dos que manipulavam e tredestinavam as informações ideológicas

36 Embora isto nāo tenha suscitado com maior profundidade na discussāo do tema, certamente mereceria reflexāo a questāo do emprego de prova ilícita como eventual elemento único de defesa em processo criminal.

37 Adaptado do texto clássico de Herbert Wechsler, Towards Neutral Principles of Constitutional Law, in Harvard Law Review 73-1 (1959).

38 Luís Roberto Barroso, Interpretação e Aplicação da Constituição, 1996, p.119 e ss. 
e pessoais dos adversários da ditadura faziam-no em nome de valores que reputavam superiores. A comparação tem sua razão de ser e apenas revela os riscos de se sacrificarem os princípios em favor de voluntarismos variados. Em seguida virão os vingadores mascarados.

Não percorremos, ainda, os ciclos do amadurecimento e da civilização. Impõese, por esta razão, algum radicalismo principiológico. Os temperamentos e atenuações terão de vir depois. Precisamos nos libertar, primeiro, do estigma da doutrina de exceção: na sala a retórica humanista, nos fundos o pau de arara. 
ALFREDOLABY FILHO

JOSE LUIZ BULHÓS PEDAEIKA

\section{A ILI DAS}

\section{S.A.}

VOLUSE II

PARECERES

$2^{2}$ volume

Ref. 0110

Encadernado

758 págs.

Form. $16 \times 23$

1996

\section{A LEI \\ DAS \\ S.A.}

Alfredo Lamy Filho

José Luiz Bulhões Pedreira

Escrito pelos elaboradores do Anteprojeto que resultou na vigente Lei 6.404 , de 1976 , este $2^{\circ}$ volume reúne pareceres sobre os temas polêmicos subscritos pelos Autores após a promulgaçāo da Lei. 